\title{
Correction to: The effect of the peritoneal tumor microenvironment on invasion of peritoneal metastases of high-grade serous ovarian cancer and the impact of neoadjuvant chemotherapy
}

\author{
J. O. A. M. van Baal ${ }^{1} \cdot$ C. A. R. Lok ${ }^{1} \cdot$ E. S. Jordanova ${ }^{1} \cdot$ H. Horlings ${ }^{2} \cdot$ W. J. van Driel ${ }^{1} \cdot$ F. C. Amant ${ }^{1} \cdot$ K. K. Van de Vijver $^{2,3}$ \\ Published online: 2 December 2020 \\ (C) Springer-Verlag GmbH Germany, part of Springer Nature 2020
}

Correction to: Virchows Archiv (2020) 477:535-544

https://doi.org/10.1007/s00428-020-02795-8

The authors regret that in the Abstract section of the original published version of the above article contained errors. They requested that these be noted [Bold text used to highlight problem area].

In the abstract originally written as "After NACT, increased ieCD3 + cells were shown, compared to no-NACT $(\mathrm{p}=0.044)$." However, this should be "After NACT, decreased stromal (s)CD3 + cells were shown, compared to no-NACT ( $\mathrm{p}=0.044)$."

Furthermore, "NACT increases abundance of ieCD3+ cells in peritoneal metastases or HGSOC." should be adjusted to "NACT decreases abundance of sCD3+ cells in peritoneal metastases or HGSOC."

Publisher's note Springer Nature remains neutral with regard to jurisdictional claims in published maps and institutional affiliations.

The online version of the original article can be found at https://doi.org/ $10.1007 / \mathrm{s} 00428-020-02795-8$

J. O. A. M. van Baal

j.v.baal@nki.nl

1 Department of Gynecology, Center for Gynecologic Oncology

Amsterdam, P.O. Box 90203, Amsterdam 1006, BE,

The Netherlands

2 Division of Diagnostic Oncology \& Molecular Pathology, The Netherlands Cancer Institute, Antoni van Leeuwenhoek Hospital, Amsterdam, The Netherlands

3 Department of Pathology, Ghent University Hospital, Cancer Research Institute Ghent (CRIG), Ghent, Belgium 